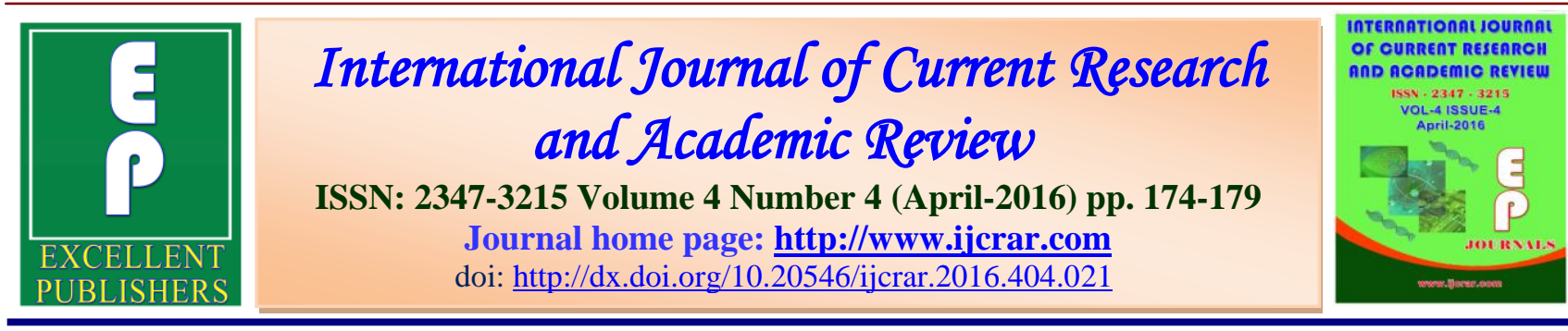

\title{
A Comparative Study of Selective Haematological Parameters of Female Sports and Non Sports Persons
}

\author{
B. Sujatha* and Sujatha Andrew \\ Department of Physiology, Tirunelveli Medical College, Tirunelveli, India \\ *Corresponding author
}

KEYWORDS

Female sports

persons,

Haemoglobin,

Red blood cell,

Anaemia.

\section{A B S T R A C T}

Haematologic tests are one among many tests used widely to assess health and fitness of sports persons. Adult sports persons exhibit changes in blood parameters which differs from those of general population. The main aim of this study includes that to find out the effect of sports on haemoglobin and red blood cell count and to compare and analyze the result of female sports persons with that of female non-sports persons. 30 female sports persons, aged between 18 to 21 years and 30 female non sports persons of same age group were selected. Height, weight, pulse rate, blood pressure were recorded. Venous blood was collected and tested in Sysmex 21, Transasia cell counter for haemoglobin and red blood cell count. Results were analyzed by independent sample' $t$ ' test. This study revealed lower haemoglobin concentration and red blood cell count in sports persons when compared to non sports persons. Endurance sports activities over a longer period reduces the haemoglobin and red blood cell count in sports persons when compared to non sports persons which improves their sports performance.

\section{Introduction}

Body fitness prolongs life (Arthur C Guyton, John E Hall, 2011). Prolonged and strenuous physical training is known to induce significant changes in haematological parameters in highly trained sports persons. Exercise improves quality of healthy life. Regular exercise prolongs life. People who regularly exercise have their physiological parameters quite different from those who do not exercise. Immediately after exercise plasma and blood volume are decreased as a result of fluid loss through sweat and respiration, filtration to the extra vascular space following an increase in arterial pressure and muscle contraction during exercise. Even in the absence of oral fluid ingestion, plasma volume is restored to baseline within minutes of exercise 
completion (Mack et al., 1998). The fluid flux into the vascular space occurs presumably to stabilize cardiovascular function, and is caused by alterations in Starling forces, elevations in plasma albumin mass, and increased renal tubule sodium absorption (Gillen et al., 1991; Hayes et al., 2000; Mack et al., 1998; Nagashima et al., 1999; Nagashima et al., 2001).When a person is exposed to aerobic exercise for longer duration there is increase in plasma volume and demonstrating decrease in red blood cell count and haemoglobin content. We are interested on female sports persons because many studies conducted were on male sports persons. In this study we analyzed certain haematological parameters like haemoglobin percentage and red blood cell count of female sports persons and compared that with female non sports persons.

The main aim of this study includes that, to find out the effect of sports on certain hematological parameters like hemoglobin and red blood cell count of female sports persons. And also to compare and analyze the hematological parameters of sports persons with that of non sports persons.

\section{Materials and Methods}

This study was conducted at Physical Education Department of Rani Anna Government College for Women in Tirunelveli. Ethical committee clearance was obtained from Tirunelveli Medical College.

\section{Inclusion Criteria}

30 sports women of age group between 18 to 21 years.

30 non-sports women of age group between 18- 21 years as control.
Sports women who were on regular training.

\section{Exclusion Criteria}

Co-morbidities like diabetes, hypertension bronchial asthma, thyroid disorders and epilepsy.

Sports women not willing for study. Sports women not on regular sports training. Sports persons on any kind of drugs.

\section{Methodology}

Informed written consent from individuals was obtained. Anthropometric measurements like height in $\mathrm{cm}$ and weight in $\mathrm{kg}$ were measured by using Stadiometer and standard human body weighing machine respectively. Pulse rate was counted by using pulse oximeter and blood pressure was recorded by using mercury sphygmomanometer. $2 \mathrm{ml}$ of venous blood from antecubital vein was collected in EDTA tube and subjected to haemoglobin and red blood cell count testing in Sysmex 21 Transasia electronic cell counter in clinical pathology laboratory at Tirunelveli Medical College Hospital. Results obtained were statistically analyzed by using Independent sample't' test by using SPSS statistical software version 11. 'p' value < 0.05 was considered as significant.

\section{Results and Discussion}

In our study, the haemoglobin content and total red blood cell count were significantly low in sports women when compared to non sports women. Pulse rate was also significantly low in sports women ('p' value $=0.005$ ). In sports women systolic blood pressure is slightly high and diastolic blood pressure is slightly low when compared with non sports women but statistically not 
significant. In our study, the haemoglobin level of female sports persons was lower than the control group. Red blood cell count was also significantly low in female sports persons when compared with female non sports persons. Syzgula, (1990) reported lowered haematological parameters in his study on endurance sports persons. He called it as 'sports anaemia'. Because a low blood haemoglobin concentration and low RBC count defines anaemia, this has been called as sports anaemia. Kehat et al. (2003) also used the term sports anaemia in his study.

Table.1 Anthropometric measurement of study group

\begin{tabular}{|c|c|c|c|c|c|}
\hline & \multicolumn{2}{|c|}{ Control group } & \multicolumn{2}{|c|}{ Sports group } & \multirow[b]{2}{*}{ P value } \\
\hline & Mean & S.D & Mean & S.D & \\
\hline $\begin{array}{l}\text { Age } \\
\text { (yrs) }\end{array}$ & 18.93 & 1.2 & 18.83 & 0.83 & 0.71 \\
\hline $\begin{array}{l}\text { Height } \\
\text { (cm) }\end{array}$ & 156.06 & 6.53 & 157.86 & 6.27 & 0.281 \\
\hline $\begin{array}{l}\text { Weight } \\
\text { (kg) }\end{array}$ & 50.96 & 9.47 & 50.5 & 6.45 & 0.824 \\
\hline
\end{tabular}

Table.2 Cardiovascular system parameters of study group

\begin{tabular}{|l|c|c|c|c|c|}
\hline \multirow{2}{*}{ Vital } & \multicolumn{2}{|c|}{ Control group } & \multicolumn{2}{c|}{ Sports group } & \multirow{2}{*}{ P value } \\
\hline Parameters & Mean & S.D & Mean & S.D & \multirow{2}{*}{ P } \\
\hline Pulse rate/min & 79.03 & 10.4 & 72.06 & 7.83 & $\mathbf{0 . 0 0 5}$ \\
\hline Systolic BP (mmHg) & 102.73 & 9.37 & 102.8 & 10.35 & 0.979 \\
\hline Diastolic BP (mmHg) & 68.86 & 4.68 & 68.6 & 6.43 & 0.855 \\
\hline
\end{tabular}

Table.3 Certain haematological parameters of study group

\begin{tabular}{|l|c|c|c|c|c|}
\hline & \multicolumn{2}{|c|}{ Control } & \multicolumn{2}{c|}{ Sports } & \multicolumn{1}{c|}{ P } \\
& Mean & S.D & Mean & S.D & value \\
\hline & & & & & \\
Hb (gm \%) & 12.41 & 1.34 & 11.68 & 1.28 & $\mathbf{0 . 0 3 6}$ \\
\hline $\begin{array}{l}\text { RBC count (in million/ } \\
\text { cmm of blood) }\end{array}$ & 4.44 & 0.35 & 4.23 & 0.35 & $\mathbf{0 . 0 2 9}$ \\
\hline
\end{tabular}


Figure.1

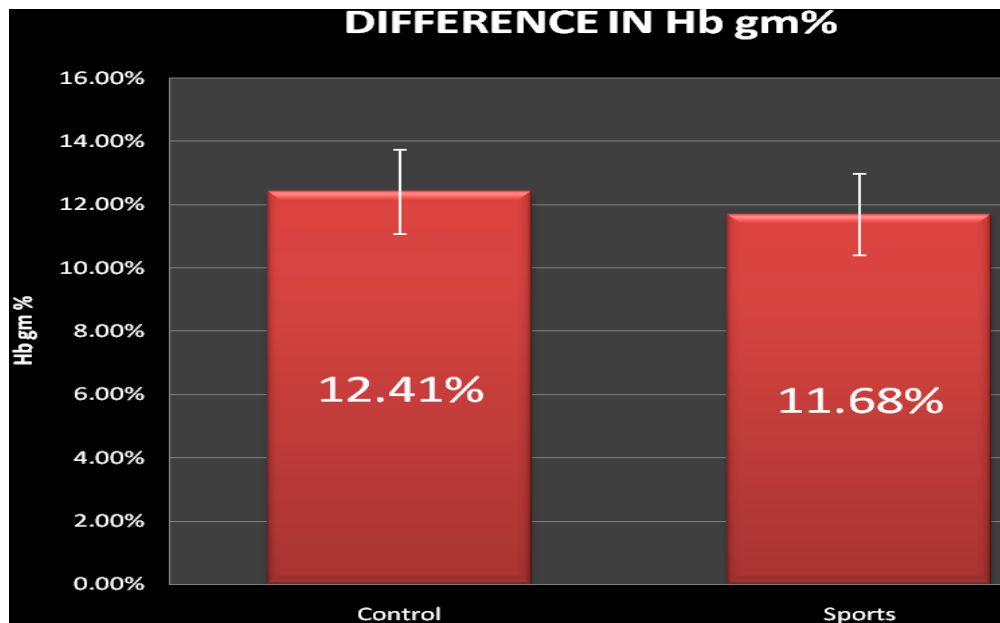

Figure.2

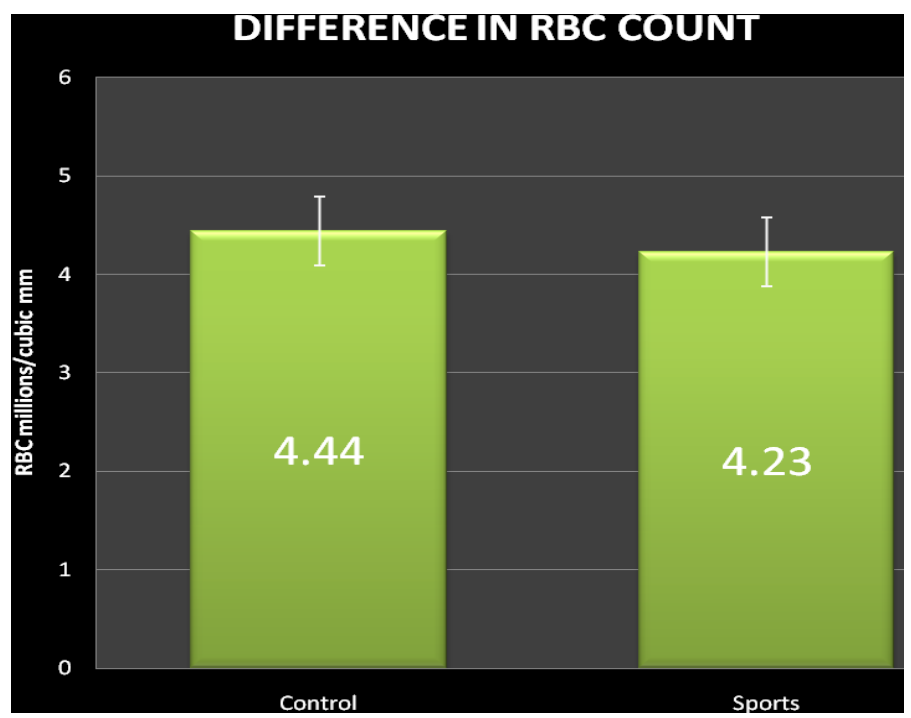

To explain this many reasons were put forward. One reason being, during physical training destruction of erythrocytes occurs that is, mechanical damage to red blood cells in foot capillaries which occurs during running. Old erythrocytes are destroyed easily because of decreased mechanical and osmotic resistance that reduces the mean age of erythrocytes in blood of athletes (Schmidt et al., 1988) This leads to decreased haemoglobin concentration in blood and lowered haematocrit value.
Many authors have found low RBC parameters in athletes and an increase in total blood volume by $12-20 \%$ (Convertino et al., 1980), haemoglobin level is decreased because exercise expands the baseline plasma volume; this reduces the concentration of red cells, which contain the hemoglobin (Convertino et al.,1980) The plasma volume post-restoration usually exceeds the original plasma volume, resulting in the phenomenon of exerciseinduced hypervolemia (Convertino, 1991; 
Gillen et al., 1991; Mack et al., 1998; Maw et al., 1996; Nagashima et al., 1999). If exercise is repeated over a number of days the resting plasma volume may increase by up to 20\% (Convertino, 1991; Convertino et al., 1980; Green et al., 1984). Furthermore, it appears that long-term training results in a chronic expansion of the extracellular volume (Maw et al., 1996). Even a single bout of intense exercise can expand the plasma volume by $10 \%$ within $24 \mathrm{hrs}$ (Gillen et al., 1991) These changes are beneficial to the sports persons. Magazanik A et al. (1988) and Weight et al. (1991) studies stress more on intravascular haemolysis, whereas Smith JA (1995) and Smith JA et al. (1995) put forward oxidative stress as a cause. $\mathrm{N}$ Boyadjiev and Z Taralov (2000) when compared sports group with control group noticed decreased haemoglobin content, RBC count and packed cell volume.

One study by Schumacher et al. (2002) in which they studied soluble transferrin receptor(sTfr) concentration, variables of iron status and haematological indices with untrained moderately trained and highly trained persons showed increased plasma volume and decreased haemoglobin and packed cell volume after several days of aerobic exercise. Study on professional athletes by Malcovati et al. (2003) also noticed haemoglobin and haematocrit values were higher at beginning of competition season, and then declined in well-trained athletes.

\section{Conclusion}

To conclude, in sports women both Haemoglobin concentration and RBC count are low when compared to non sports person resulting in sports anaemia due to plasma volume expansion which is the chief contributing factor. In fact, these changes make them a better Athlete and render them improved performance.

\section{Acknowledgement}

We sincerely thank The Principal and Head, Department of Physical Education for their valuable support and co operation and also the students of Rani Anna Government College for Women, Tirunelveli for their active participation in this study. We would also like to thank the paramedical staff of Clinical Pathology Laboratory, Tirunelveli Medical College for their help and kind co operation.

\section{References}

Arthur, C., Guyton, John, E. 2011. Hall: Textbook of Medical Physiology: twelfth edition Philadelphia, PA 19103-2899 Saunders Elsevier.

Convertino, et al. 1980. Exercise training induced hypervolemia: role of plasma albumin, renin and vasopressin1980, J. Appl. Physiol., 48: 665-66.

Convertino, V.A.1991. Blood volume: its adaptation to endurance training. Med. Sci. Sports Exerc., 23(12): 1338-48.

Gillen, C.M., Lee, R., Mack, G.W., Tomaselli, C.M., Nishiyasu, T., Nadel, E.R. 1991. Plasma volume expansion in humans after a single intense exercise protocol. J. Appl. Physiol., 71(5):1914-20.

Green, H.J., Thomson, J.A., Ball, M.E., Hughson, R.L., Houston, M.E., Sharratt, M.T. 1984. Alterations in blood volume following short-term supramaximal exercise: J. Appl. Physiol. Respir. Environ. Exerc. Physiol., 56(1): 145-9.

Hayes, P.M., Lucas, J.C., Shi, X. 2000. Importance of post-exercise hypotension in plasma volume 
restoration. Acta Physiol. Scand., 169(2): 115-24.

Kehat, I., Shupak, A., Goldenberg, I., Shoshani, O. 2003. Long-term haematological effects in special Forces trainees: Mil Med., 168(2): 116-119.

Mack, G.W., Yang, R., Hargens, A.R., Nagashima, K., Haskell, A. 1998. Influence of hydrostatic pressure gradients on regulation of plasma volume after exercise. J. Appl. Physiol., 85(2): 667-75.

Magazanik, A., Weinstein, Y., Dlin, R.A., Derin, M., Schwartzman, S., Allalouf, D. 1988. Iron deficiency caused by 7 weeks of intensive physical exercise. Eur. J. Appl. Physiol., 57: 198-202.

Malcovati, L., Pascutto, C., Cazzola, M. 2003. Haematologic passport for athletes competing in endurance sports: a feasibility study: Haematologica, 88(5): 570-81.

Maw, G.J., MacKenzie, I.L., Comer, D.A., Taylor, N.A. 1996. Whole-body hyperhydration in endurance-trained males determined using radionuclide dilution. Med. Sci. Sports Exerc., 28(8): 1038-44.

Boyadjiev, N., Taralov, Z. 2000. Red blood cell variables in highly trained athletes: a comparative analysis. $\mathrm{Br}$. J. Sports Med., 34: 200-204.

Nagashima, K., Mack, G.W., Haskell, A., Nishiyasu, T., Nadel, E.R. 1999. Mechanism for the posture-specific plasma volume increase after a single intense exercise protocol. J. Appl. Physiol., 86(3): 867-73.

Nagashima, K., Wu, J., Kavouras, S.A., Mack, G.W. 2001. Increased renal tubular sodium reabsorption during exercise-induced hypervolemia in humans. J. Appl. Physiol., 91(3): 1229-36.

Schmidt, et al. 1988. Training induced effects on blood volume, erythrocyte turn over and haemoglobin oxygen binding properties. Eur. J. Appl. Physiol., 57: 490-498.

Schumacher, Y.O., Jankovits, R., Bulttermann, D., Schmid, A., Berg, A. 2002. Haematological indices in elite cyclists. Scand J. Med. Sci. Sports, 12(5): 301-8.

Smith, J.A. 1995. Exercise, training and red blood cell turn over. Sports Med., 19: 9-31.

Smith, J.A., Kolbuch -Braddon, M., Gillam, I., Telford, R.D., Weidemann, M.J. 1995. Changes in susceptibility of red blood cells to oxidative and osmotic stress following sub - maximal exercise. Eur. J. Appl. Physiol., 70: 427-36.

Syzgula, Z. 1990. Erythrocyte system under the influence of physical exercise and training. Sports Med., 10: 181-97.

Weight, L.M., Byrne, M.J., Jacobs, P. 1991. Hemolytic effects of exercise. Clin. Sci., 81: 147-52.

\section{How to cite this article:}

Sujatha, B., and Sujatha Andrew. 2016. A Comparative Study of Selective Haematological Parameters of Female Sports and Non Sports Persons. Int.J.Curr.Res.Aca.Rev.4(4): 174-179. doi: http://dx.doi.org/10.20546/ijcrar.2016.404.021 